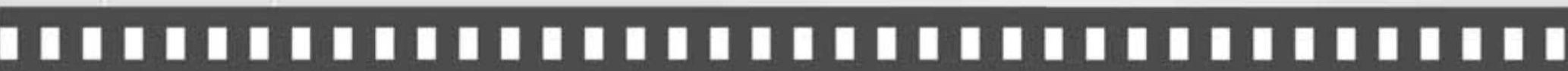

\author{
Mostrar por Montaje. Narraciones \\ Benjaminianas desde el archivo y la fotografía \\ de prensa

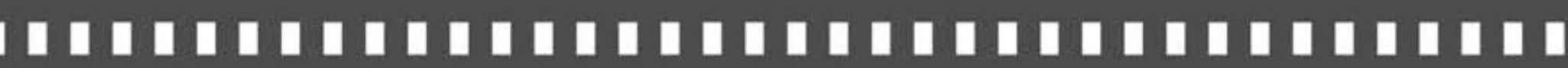

Francisco José García-Ramos

Artigo recebido em: 12/12/2018

Artigo aprovado em: 27/04/2020 


\title{
Mostrar por Montaje. Narraciones Benjaminianas desde el archivo y la fotografía de prensa
}

\author{
Showing by Montage. Benjamin's narratives \\ from the archive and the press photography
}

Francisco José García-Ramos*

Resumen: Partiendo del método de montaje de Walter Benjamin y la dys-posición de imágenes de Didi-Huberman, este artículo pretende promover una reflexión teórica y metodológica a la hora de trabajar con archivos de fotografía de prensa y hemerotecas. Una cartografia articulada mediante constelaciones fotográficas que ofrece una aproximación a otros modos de hacer narraciones historiográficas desde los márgenes de los grandes relatos de la historia.

Pabras clave: Benjamin. Método de montaje. Fotografia. Metodologia visual.

\begin{abstract}
Abstact: From Walter Benjamin's montage method and the DidiHuberman's image dys-position, this article intends to promote a theoretical and methodological reflection when working with photo-press archives and newspaper libraries. A cartography articulated through photographic constellations that offers an approach to other ways of making historiographical narratives from the margins of the great stories of history.
\end{abstract}

Keywords: Benjamin. Montage method. Photography. Visual methodology.

* Depto. Ciencias de la Comunicación Aplicada, Fac. Ciencias de la Información, Universidad Complutense de Madrid. 


\section{Introducción}

El analfabeto del futuro no será un iletrado, sino el ignorante en materia fotográfica. (Moholy-Nagy, La fotographie dans la réclame, 1927)

Valorada por algunos de los más destacados pensadores de su tiempo como Theodor Adorno o Bertolt Brecht, la recepción de la obra de Walter Benjamin (Berlín, 1892 - Portbou, 1940) es, a día de hoy, una referencia clave para el pensamiento crítico no solo filosófico-, sino también político, histórico, artístico y literario de nuestra contemporaneidad. Ocho décadas después de su muerte, Walter Benjamin sigue siendo un intérprete privilegiado de las transformaciones que nos tenía prepadado el tránsito hacia el nuevo siglo: la mercantilización generalizada, las nuevas formas cognoscitivas, la crisis de la experiencia histórica tradicional o las propuestas estéticas en un contexto tecnológico avanzado.

El cuestionamiento que el corpus benjaminiano plantea sobre la experiencia histórica tradicional y su crítica a los mecanismos por los se configuran y legitiman los grandes relatos historiográficos permiten, a día de hoy, seguir problematizando sobre los aspectos que hacen posible una concepción crítica de la historia así como del estatus que el documento desempeña en dicha articulación. Y es que "no existe un documento de la cultura que no lo sea a la vez de la barbarie. Y como en sí mismo no está libre de barbarie, tampoco lo está el proceso de transmisión por el cual es traspasado de unos a otros." (BENJAMIN, 2009, p. 43). 
En este sentido, y en consonancia con la misión del historiador de "pasarle a la historia el cepillo a contrapelo" (BENJAMIN, 2009, p. 43), expuesta en su séptima tesis de la historia, el método de trabajo por montaje resulta especialmenente relevante como dispositivo de generar conocimiento historiográfico y de iluminar, en este ejercicio de cepillado, otras historias posibles que permitan comprender y comprendernos desde otras posiciones.

La decisión de mostrar por montaje, es decir por dislocaciones y recomposiciones de todo... será un método de conocimiento y un procedimiento formal nacido de la guerra que toma acta del desorden del mundo. Firmaría nuestra percepción del mundo tras los conflictos del siglo XX: se habría convertido en el método moderno por excelencia (DIDI-HUBERMAN, 2008, p. 98).

Al hilo de estos supuestos, lo que aquí se plantea es una cartografía - entendida a modo de esbozo - para transitar teórica y conceptualmente por archivos fotográficos de prensa, ya se encuentren incompletos, fragmentados o deteriorados total o parcialmente, en aras de entenderlos como un espacio de trabajo apto para generar una re-escritura literaria de la historia a través de la técnica del montaje definida por Benjamin en El libro de los Pasajes:

Método de este trabajo: montaje literario. No tengo nada que decir. Sólo que mostrar. No hurtaré nada valioso, ni me apropiaré de ninguna formulación profunda. Pero los harapos, los desechos, esos no los quiero inventariar, sino dejarles alcanzar su derecho de la única manera posible: empleándolos. [N1a, 8] (BENJAMIN, 2005, p. 462). 
En cualquier caso, trabajar y mostrar por montaje no se presenta tarea fácil. En ocasiones nos situamos frente a archivos de fotografía de prensa que carecen de una descripción o pie de foto, del cuerpo de su crónica o de datación precisa. Por otro lado, los conjuntos hemerográficos permitirán acceder a una imagen fotográfica ya reproducida mecánicamente y situada por el dispositivo epigráfico de los textos que la acompañan. Esta dificultad a la hora de leer una imagen, paso previo para establecer de una dialéctica entre ellas generadora de nuevos conocimientos, ya fue señalada en 1955 por Ruth Berlau en su texto para el $A B C$ de la Guerra de Bertolt Brecht. Sus palabras nos advierten que "al no instruido le es tan difícil leer una imagen como cualquier jeroglifico" pues "la gran ignorancia sobre las relaciones sociales... convierte las miles de fotografías publicadas en las revistas ilustradas en verdaderos jeroglificos, indescifrables para el lector ignorante" (BERLAU, 2004, p. 7).

Conscientes de esta dificultad $-\mathrm{y}$ con el fin de profundizar en las posibilidades de escritura que ofrece el método de montaje benjaminiano cuando se trabaja con archivos fotoperiodísticos-, las páginas siguientes tienen como objetivo confrontar la técnica por montaje con el discurso de algunos autores que, por un lado, han abundado en las posibilidades narrativas de la disposición de imágenes y textos fragmentarios $\mathrm{y}$, por otro, con aquellos que plantean nuevas propuestas de escritura historiográfica al margen de los relatos hegemónicos y que se adscriben de manera implícita o manifiesta al pensamiento benjaminiano. Será, precisamente, el trenzado dialéctico de unas y otras referencias lo que permita establecer el marco teórico a través del cual atisbar constelaciones fotográficas donde puedan orbitar textos periodísticos e imágenes de 
prensa, aparentemente muy dispares, en una misma narración.

\section{Constelaciones Fotográficas}

Trabajar mediante montaje con las imágenes conservadas en archivos de fotografía de prensa y conjuntos hemerográficos supone, siguiendo la estela benjaminiana, poner en práctica una arqueología de archivo a través de la cual poder revisualizar, repensar y rescribir la historia proponiendo otras narraciones fruto de las nuevas dialécticas generadas entre las imágenes y los textos.

De esta forma, el conjunto de imágenes pueden salir a la luz orbitando al margen de un continuum preciso. Como fragmentos de historia inconclusa, las fotografías podrán entenderse como un sistema y un relato de estructura non finita. Un sistema de imágenes entrelazado por múltiples entramados y prácticas discursivas que, estrato tras estrato, irán conformando una gran constelación de imágenes.

Como los paneles del Atlas Mnemosyne de Aby Warburg (2010), que están relacionadas de forma aún más inmediata con la teoría del conocimiento benjaminiana, la constelación resultante de esta arqueología de archivo atenderá a una reflexión sobre la memoria elaborada a través de la dys-posición, siguiendo el análisis de DidiHubermann (2008) del trabajo de Bertolt Brecht, de centenares de imágenes y textos de procedencia diversa y susceptibles de modificación por parte del investigador.

El punto de partida será el mismo que el del coleccionista de fragmentos. Coleccionista no entendido como el esteta exquisito a la búsqueda de lo sublime, sino más bien como el trapero, el 
chiffonnierl $^{l}$ al que se aludía en el poema de Baudelaire de Las flores del mal (1857). Como un espigador de la cultura que rastrea sus desechos, la labor arqueológica de archivo puede concebirse como un ejercicio de recopilación de imágenes de prensa que nunca hayan ocupado importantes portadas, lugares destacados en las secciones más importantes o espacios coronados por grandes titulares. Una labor que busca cepillar a contrapelo lo noticiable de la historia, lo consideraro digno de ser visto y contado: "lo decible", empleando las palabras de Foucault (2009) en La arqueología del saber.

Alejado de todo continuum, será desde el fragmento, la ruina y la fisura donde poder alcanzar un proceso cognoscitivo a modo de una "iluminación profana" donde el iluminado se presente como "el lector, el pensador, el esperanzado, el flâneur" (BENJAMIN, 2007, p. 314). Lo que se propone, por tanto, es un deambular entre imágenes y textos que consiga transformar la mirada histórica de lo que ya ha sucedido, tal y como era el objetivo de Benjamin: "destruir la inmediatez mítica del presente, no insertándola en un continuum cultural que afirma el presente como su culminación, sino descubriendo aquella constelación de orígenes históricos que tiene el poder de hacer explotar el 'continuum' de la historia" (BUCKMORSS, 1996, p. 14).

Por otro lado, habrá que atender también al aviso de Benjamin

1 A menudo y a luz roja del farolillo cuya llama y cristal azota y golpea el viento en pleno barrio arrabalero, laberinto de fango donde hierven los hombres en fermentos tormentosos, suele pasar un trapero. La cabeza gacha, tropezando y chocando en los muros lo mismo que un poeta, no se preocupa de los soplones, súbditos suyos son, y alivia el corazón con proyectos grandiosos. Traducción libre del poema "Le Vin de chiffonniers" de Les Fleurs du mal, editado por primera vez en París en 1857. Para una edición bilingüe del poema original de Baudelaire ver: (LÓPEZ CASTELLÓN, 2003, p. 236-239). 
cuando nos advierte que se nos muestra "imágenes de la cultura del pasado muy incompletas" y que "la vemos... en sus suntuosos ropajes de los días de fiesta, y sólo muy pocas veces en un traje, generalmente raído, de las jornadas de trabajo»" (BENJAMIN, 1989, p. 131). De este modo, el sistema de constelaciones que aquí se propone además de ser un pobre vestido de diario cuenta con la marginalidad añadida que supone legitimar como válidos archivos olvidados, menores o faltos de una catalogación precisa de fotografía de prensa de naturaleza analógica. Y de manejar, por otro lado, cabeceras de prensa y revistas exentas del estatus privilegiado de construir los grandes relatos de los aconteceres de la historia.

En relación al estatus que históricamente se le ha atribuido a la fotografía de prensa, hay que recordar que hasta fechas muy recientes su valor y función informativa, en términos puramente periodísticos, se ha privilegiado siempre a cualquier dimensión artística de la imagen. Factor que, por otro lado, hacía del chilé y la tira de negativos - una vez publicada la fotografía en el diario o revista - un documento visual caduco y en la mayoría de los casos no merecedor de ser archivado, conservado o musealizado.

El olvido y las políticas de desecho y destrucción al que se han visto históricamente condenados los chichés y las fotografías de prensa, convierte a estos corpus de imágenes en un dispositivo visual en ruinas compuesto por material fragmentario. Fotografías dispersas - en ocasiones sin pie de foto y sin datar — pero que como imágenes supervivientes se vislumbran como altamente interesantes para ser recolectadas como portadoras de memoria. De acuerdo con Benjamín (1989, p. 160-161), la memoria es el medio a través del cual se pueden desenterrar los secretos lejanos del pasado, de la 
tradición, rescatarlos de la oscuridad y revelarlos en el presente. Así, tanto a través de la idea de una excavación arqueológica como la del coleccionar, el pasado aparecerá como una topografía del recuerdo.

Al igual que el hombre que cava intentando salvaguardar la historia, solo en un mundo en ruinas se podrá construir una red de encrucijadas en cuyo intersticio espacio-temporal se posibilite el contacto con el presente y el despertar de "la consciencia del hombre histórico". Es decir, la del hombre que está "siempre en la encrucijada" (BENJAMIN, 1989, p. 160-161).

En este sentido, Benjamin señala que la "encrucijada" donde el "hombre histórico" se encuentra implica una nueva posición que le sitúa entre un pasado y un presente: en la dialéctica del tiempo histórico de los fragmentos y no en el continuum temporal de una totalidad. De esta forma, y como apunta Weigel(1999), los fragmentos del pasado aproximados a través de la actividad arqueológica o destructiva propondrán nuevos modos de pensar la historia.

Como hombre que cava, Benjamin rastreó incansablemente la Bibliothéque Nationale de France como un auténtico trapero de citas para conformar la síntesis de sus preocupaciones metodológicas: la inacabada Obra de los pasajes, donde los propios textos se utilizan como materiales opacos cuyo sentido surge de su combinatoria.

Este acto de rastreo en hemeroteca, que tiene tanto de trapeo y espigador como de arqueólogo de archivo - en el sentido que le dará Foucault (2009), para quien el valor de la práctica arqueológica será la especificación y descripción de lo que hasta ahora se había mantenido excluido, oculto, ignorado o indigno de la visibilidad histórica- será lo que determinará una de las características fundamentales de estas constelaciones fotográficas. 


\section{Mostrar por montaje / dys-poner imágenes}

La aproximación bejaminiana a los archivos hemerográficos y de fotografía de prensa como un espacio en ruinas, fragmentado e incompleto, posibilita usar en términos de dys-posición las copias positivadas de originales, chilés de distinta naturaleza, hojas de contactos y, de forma especial, el corpus de fotografías reproducidas mecánicamente a modo de reportaje en el propio medio impreso. Lo determinante de este enfoque será la pertinencia de trabajar con la propia reproducción mecánica de la fotografía y su multiplicación en serie en un medio de comunicación de masas, tal como señala el propio Benjamin en 1936 en La obra de arte en la época de su reproductibilidad técnica.

La fotografía reproducida en el propio diario se concebirá, por tanto, como un original en sí mismo al escapar de la concepción primigenia del fotoperiodista que la hizo. El propio proceso de reproducción mecánica implica una serie de modificaciones técnicas sobre la fotografía original, desde el encuadre hasta el contraste, que hace que la fotografía reproducida en el medio de comunicación se convierta, en sí misma, en un nuevo original.

Dado que "dys-poner las cosas es una manera de poderlas comprenderlas dialécticamente" (DIDI-HUBERMANN, 2008, p. 104), el conjunto total de fotografías seleccionadas por el propio medio impreso - recortadas, reencuadradas, modificadas en su calidad técnica y, por último, recontextualizadas por el texto, titulares, pie de foto y ubicación dentro del periódico o revista — será lo que conforme el estatus epigramático de todas ellas y del sistema 
de dys-posición de imágenes de la constelación fotográfica²

De forma consustancial a la recolección del fragmento y de la ruina, la configuración por montaje de estas constelaciones fotográficas no implicará necesariamente el uso de la totalidad del archivo fotográfico. Bastará una selección del mismo para, en torno a ellos, establecer sistemas que articulen el discurso no de forma cerrada y excluyente, sino abierta y permeable al resto de reportajes.

Tal y como señala Didi-Huberman (2008, p. 78-81), para Bertolt Brecht el arte de la historización es un arte que rompe la continuidad de las narraciones y extrae de ellas diferencias. Será al componer esas diferencias juntas, cuando se restituye el valor esencialmente crítico de toda historicidad. En este sentido, el distanciamiento será un elemento clave en el proceso. Para Brecht, "distanciar" es saber manipular el material visual y narrativo como un montaje de citas que hacen referencia a la historia real, como muestra la mesa de montaje que fue su Diario de trabajo (19381955). El distanciamiento posibilita crear intervalos allí donde solo se ve unidad. El montaje crea adjunciones nuevas entre órdenes de realidad pensados espontáneamente como diferentes, desarticulando nuestra percepción habitual de las relaciones entre las cosas o las situaciones.

2 En un texto de 1935 titulado Cinco dificultades para escribir la verdad, inicialmente destinado a su publicación clandestina en la Alemania, Bertolt Brecht afirmaba que la dialéctica no es solo una cuestión de método. Señala que hace falta el valor de escribir la verdad, la inteligencia de considerar las situaciones más fecundas, el discernimiento para saber a quién confiar la verdad, la astucia para difundirla y finalmente el arte de hacerla manejable como un arma. De ahí la necesidad de interrogar todas las cosas y todos los acontecimientos por lo que tienen de efímeros y variables. Brecht advertía que los que ostentan el poder sienten una gran aversión al cambio y quisieran que todo permaneciera igual, con preferencia, miles de años. Ver: DIDI-HUBERMAN (2008, p. 106-107). 
Las imágenes, como superficies privilegiadas de inscripción de complejos procesos memoriales, podrán conformarse en constelaciones que actúen como instrumentos para poder leer el tiempo. Esto es, poder leer imágenes "para que el tiempo tenga una oportunidad de ser descifrado de nuevo" (DIDI-HUBERMAN, 2008, p. 43).

Si "la verdad es concreta" (BERLAU, 1955, p. 199 apud DIDI-HUBERMAN, 2008, p. 109) —es decir — "singular, parcial, incompleta, pasajera como una estrella fugaz" (DIDI-HUBERMAN, 2008, p. 109). El lector de estas constelaciones de estrellas fugaces - tendrán en estos pequeños destellos de flash de cámaras fotográficas, trocitos de verdad dispersos aquí y allá en una $d y s-$ posición de imágenes, textos de crónicas periodísticas y pies de foto. De esta forma el lector, más que espectador, se convertirá en un "expectador" — en su calidad de ser expectante- de una utilización literaria de la fotografía en aras de una construcción narrativa posibilitadora de una historia otra:

Porque está atravesada por la memoria y ser ella misma vehículo de memoria, la imagen fotográfica admite aquí, por el truncamiento suplementario del epigrama que subraya su antigüedad virtual, una función épica, alegórica y lírica, como trasgrediendo su naturaleza inmediata de documento de la historia. Se podría decir que la complejidad y la plasticidad temporales del médium fotográfico - mucho más allá, por tanto, del famoso "ha-sido" barthesiano- se revelan constitucionalmente aptas para este tipo de atravesamientos o transparentamientos de la memoria de la historia. De ahí esta posibilidad de lirismo documental inherente a las utilizaciones literarias más notorias de la fotografía (Didi-Huberman, 2008, p. 208-209). 


\section{Dys-posiciones verbovisuales}

El análisis crítico de este gran sistema de constelaciones se basa en la yuxtaposición dialéctica de fotografía de prensa y textos periodísticos indagando en la posibilidad literaria apuntada por Didi-Hubermann (2008). Conscientes de los sesgos que puedan desprenderse de este planteamiento, ya que se trata de una modesta aproximación cartográfica para dys-poner textos verbovisuales, esta propuesta tratará de llegar a dibujar constelaciones de sentido, de "imágenes que piensan" (BENJAMIN, 2012). Es decir, un conjunto de retículas de conexiones significativas entre elementos aparentemente independientes y distantes, ya sea en el tiempo o en el espacio, de los distintos reportajes publicados en el medio impreso o conservados total o parcialmente en sus archivos fotográficos.

Esta exploración transversal busca conciliar la mirada sociosemiótica con el análisis de los procesos culturales. De esta forma, se pretende abordar el texto visual haciendo uso de una metodología de investigación cualitativa atendiendo a Van Dijk (1993) en el estudio interdisciplinario de las noticias y el discurso, a Mitchell $(1994,2009)$ y su «giro de la imagen» — pictorial turnproducido en el seno de lo que Abril (2008) ha denominado «cultura verbovisual».

A partir del supuesto de que la visualidad y las operaciones visuales están culturalmente construidas, la revisión historiográfica que se propone queda, al tiempo, atravesada en su construcción como relato por la revalorización que plantea Sánchez Vigil (2001), Burke (2005), Cadava (2006) o Collingwood-Selby (2009) del uso la imagen fotográfica como documento histórico atendido tanto al 
uso y los usos del hecho fotográfico como a su valor heurístico, de producción de conocimiento.

De esta manera, las observaciones que engarzan la gran red de fotorreportajes estarán, inevitablemente, cargadas y pretextualizadas por los presupuestos de una cultura visual, de un imaginario compartido y de un modo histórico de mirar: el del propio fotoperiodista, el del medio impreso y el de la sociedad en donde se inscribe. Y es que, más allá de que quien lee a través de los ojos es un yo, "también lo es la instancia impersonal o transpersonal de un 'se' (de 'se lee') determinado por pautas aprióricas, normativas, a menudo ideológicas, de atención, selección y acotación de la realidad visible de que se trate" (ABRIL, 2008, p. 13).

Esta rearticulación verbal de la experiencia visual a modo de gran écfrasis, podrá abordarse desde una posición micro y macro sociológica y desde la pluri y transdisciplinaridad que requiere una investigación de historia de las mentalidades, de la vida cotidiana y del uso y los usos de la fotografía.

En este sentido, ya Hamburger (1986, p. 40) hablaba de "cesura" a esta suerte de discontinuidad que impide al historiador "unificar totalmente los resultados que obtiene sobre el mismo objeto, en escalas y métodos diferentes". Reconocidas esas cesuras, y desplazándonos hacia espacios de enunciación esencialmente cualitativos, esta propuesta intenta interconectar las posibilidades metodológicas que ofrecen las humanidades y las ciencias sociales a la hora de plantear un ejercicio de rescritura desde el hecho fotoperiodístico aun cuando la exposición pueda vislumbrar un tono ensayístico e incluso rapsódico.

La mirada sociosemiótica que plantea el análisis visual de las 
constelaciones fotográficas no apunta tanto a saber qué significan los textos visuales sino en investigar los modos y los medios por los que llegamos a atribuirles tales significados. Esta exploración de los procesos de sentido en que intervienen será fundamental para establecer una dinámica interpretativa en la que, tomando como punto de partida la semiosis ilimitada de Peirce (1974), "los textos visuales han de verse también como formas fluyentes, dinámicas, nunca plenamente determinadas, en redes textuales movedizas en el tiempo de la historia y en los espacios de la cultura” (ABRIL, 2008, p. 19).

Por tanto, y siguiendo la metodología visual crítica que propone Rose (2001), estas constelaciones podrán abordarse desde de una estrategia orientada a analizar prácticas textuales verbovisuales en términos de su significación cultural, de las prácticas sociales que las articulan, de las relaciones de poder que las conforman así como de las ideologías que las legitiman, cuestionan y que son expresión, en términos de Jameson (1998) de su "inconsciente político".

La función indicial -en términos peircinaos- del documento fotográfico habrá de ser considerada, al tiempo, como parte de una cultura mediática en pleno desarrollo y como engranaje de una experiencia visual ampliada — en cierto modo sinestésicadel ecosistema mediático en el cual se inscriben los diarios y revistas del archivo hemerográfico o del archivo fotoperiodístico.

Como un gran collage expandido - a la manera del poema de Mallarmé (2013) Un lance de dados jamás abolirá el azar (1897) - las imágenes se irán dys-poniendo dialécticamente como proceso situado de enunciación, interpretación y acción reflexiva. Una práctica sociodiscursiva, multiacentuada y nunca definitivamente fijada, que 
permita generar, tanto en sentido sincrónico como diacrónico, nuevos procesos de lectura y pensamiento sobre nuestra historia reciente. Una perspectiva que entenderá la fotografía de prensa como un índice factorial - en tanto que la práctica del fotoperiodismo forma parte de una red de relaciones con otras prácticas no solo textualessiempre interceptado por un afuera.

En el pensamiento de Bajtin (1970, p. 242) el texto no se concibe como una entidad estable sino como un proceso, un devenir de solapamientos, hibridaciones y ósmosis entre fragmentos textuales previos, lenguajes y perspectivas sociosemióticas. De este modo, la problemática intertexual y la intratextual viene en gran medida a superponerse. La voz del autor o autora - ya hablemos del o de la fotoperiodista o del redactor o la redactora que genera relato sobre los hechos noticiables, no será, por tanto, única, indivisa, sino más bien "el lugar de encuentro entre voces en cuya pluralidad el texto se abre inexcusablemente a la relación con otros textos" (ABRIL, 2008, p. 82).

Esto lleva a asumir la elaboración de estas constelaciones, por un lado, desde el llamamiento de Kracauer (2009) por descubrir lo oculto en el texto investigando su propia exégesis. Y, por otro, desde el enfoque exoinmanentista de Abril (2008) bajo el que "las prácticas sociales y, por ende discursivas, representan a la vez un 'interior' y un 'exterior' del texto" que impiden "agotar las posibilidades de expresarlo en su (ni como una) totalidad" (ABRIL, 2008, p. 97).

Por último, señalar la posibilidad de que las constelaciones puedan disponerse a modo de fábula o trama narrativa para recorrer, desde su propia esencia fragmentaria, la gran estructura del imaginario mediático tanto desde una perspectiva diacrónica como sincrónica. 
Así, tanto los acontecimientos fotografiados como los personajes retratados entrarán en escena como dramatis personae: personajes dispuestos a la identificación con el espectador susceptibles de configurar todo un repertorio de arquetipos y roles míticos. En palabras de Apollinaire: "las fábulas ya están realizadas en su mayor parte, y ahora compete a los poetas imaginar fábulas nuevas, unas que a su vez los inventores puedan nuevamente realizar" (apud BENJAMIN, 2007, p. 300).

\section{Otras narraciones para materializar el pasado}

Enfrentarse a un archivo de fotografía de prensa supone, al tiempo, interrogarse sobre las condiciones de trabajo del propio medio impreso, línea editorial, valor y protagonismo que otorgan a

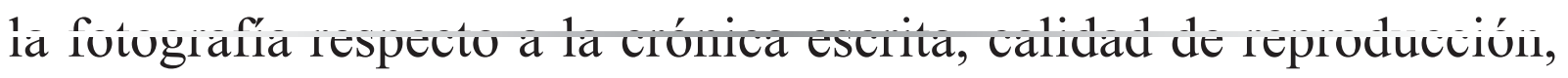
nolíticas de re-encuadre, retoque, manipulación y escenificación de lo fotografiado, entre otras muchas consideraciones. Cuestiones que deben extenderse, en un proceso de poner en valor las fuentes orales como herramienta de generar conocimiento historiográfico, a los sujetos entrevistados en relación a los modos de ficcionar los hechos de los que se ha sido testigo o los modos en que opera el olvido en la manera de articular el recuerdo y justificar, explicar y entender el presente.

Asimismo, y en relación a la barbarie que habita también en todo proceso de transmisión de los documentos de cultura, cabría preguntarse también cómo desarticular las prácticas de poder de los agentes sociales y los medios de comunicación a la hora de poner en marcha esos mecanismos de transmisión. 
Hernández Navarro (2012) en Materializar el pasado. El artista como historiador (benjaminiano) recoge tres modelos o estrategias que logran condensar el maremágnum de prácticas históricas que, desde la fotografía, el vídeo y otros lenguajes propios del arte contemporáneo, reflexionan sobre las posibilidades que brinda el pensamiento de Walter Benjamin para ensayar nuevas formas de narración.

El primer nodo, al que denomina "historias paralelas" tratará de promover visiones de la historia más allá de los grandes relatos visibilizando "historias que han pasado desapercibidas y que, sin embargo, forman parte del pasado. Historias puntuales, singulares, personales pero que están penetradas por la historia colectiva" (HERNÁNDEZ-NAVARRO, 2012, p. 36). Una aproximación que intenta contar la historia que está en los márgenes de lo que se ha contado, la historia oscurecida, la historia imperceptible más allá de las grandes narraciones.

El segundo nodo será aquel que trabaja con "historias alternativas". Es decir, aquellas que son creadas a través de narrativas ficcionales o especulativas:

Se trata aquí de historias posibles o verosímiles, historias que podrían haber pasado. La verosimilitud y la posibilidad se convierten en elementos que pueden afectar el presente. Una especie de historia especulativa donde "la verdad" se vuelve irrelevante. Sucede, por ejemplo, [...] en obras donde se parte de ciertas verdades históricas para reconstruirlas y modificarlas de manera intuitiva y creativas, en arqueologías ficticias y pseudohistóricas, [...], trabajos en torno al anacronismo, la utilización de elementos del pasado para contar el presente o proyecciones del presente para contar el pasado. Estos artistas intentan rescatar el 
pasado que quedó varado y traerlo hasta el presente, prolongando los hilos que fueron cortados y tomando consciencia de que la historia podría haber sido de otra manera (HERNÁNDEZ-NAVARRO, 2012, p. 37).

Por último, el tercer nodo - en donde parecen confluir los dos anteriores - camina hacia "la deconstrucción de los modos en los que la historia ha sido construida mostrando sus puntos ciegos para evidenciar su artificialidad. Se trata de intentos de desvelar la ideología y la contingencia de las construcciones" (HERNÁNDEZNAVARRO, 2012, p. 37). Aquí, las estrategias de extrañamiento, las manipulaciones del tiempo o la performativización poética de actos históricos singulares evidencian la estrecha frontera entre realidad y ficción que opera en toda construcción histórica. Una propuesta, en definitiva, que incide en la participación de elementos de ficción mítico-literarios en todo proceso de construcción historiográfica.

\section{A Modo de Conclusión}

En 1953 Maurice Jarnoux fotografió a André Malraux completamente rodeado de imágenes mientras trabajaba sin descanso en su Museo Imaginario. La fotografía, publicada en 1954 en el número de 19 de junio de la revista Paris Match, visualiza lo que podría ser la mesa de trabajo de quienes guiados - con mayor o menor acierto - por la cartografía que aquí se plantea, transiten como arqueólogos o arqueólogas por las profundidades del archivo en aras de articular constelaciones fotográficas mediante el método de montaje y la dys-posición de imágenes.

Esta aproximación al archivo, tal y como expuso Foucault 
en 1969 en La arqueología del saber, va más allá del conjunto de documentos, registros o datos que una cultura guarda como memoria y testimonio de su pasado. Ni siquiera se refiere a la institución encargada de conservarlos. Para Foucault, el archivo es lo que permite establecer la ley de lo que puede ser dicho (las cosas dichas), el sistema que rige la aparición de los enunciados como acontecimientos singulares o el conjunto de reglas que caracterizan una práctica discursiva. En definitiva, lo decible. Lo que configura el aparato de verificación, el discurso de verdad de una sociedad.

Bajo este planteamiento, el archivo no se puede describir exhaustivamente. Al carecer de límites será imposible concebirlo en su totalidad. Ante el archivo, solo queda la aproximación fragmentaria. ¿Cómo recoger entonces ese troceamiento del mundo? Hacer un atlas — nos advierte Didi-Hubermann (2008) — significa renunciar al cuadro sintético. Lo preferible será, por tanto, disponer las cosas como en una mesa o en un tablero y observarlas según la cualidad particular, modificable al antojo de recomposiciones siempre posibles, de sus múltiples encuentros.

La metodología que aquí se ha expuesto pretende, siguiendo la senda benjaminiana, una arqueología de archivo a través de la cual poder revisualizar, repensar y rescribir la historia dys-poniendo las imágenes de archivos de fotografía de prensa. Todo un dispositivo de imágenes que salen a la luz orbitando al margen de un continuum preciso, como un sistema y un relato de estructura non finita.

Un sistema de imágenes que se entrelaza por múltiples entramados y prácticas discursivas que, estrato tras estrato, conforman lo que se ha denominado constelaciones fotográficas.

Primer estrato. Constituye el acto de rastreo en hemeroteca, 
que tiene tanto de trapeo y espigador como de arqueólogo de archivo, en el sentido que le dará Foucault. Aquí, el valor de la práctica arqueológica será la especificación y descripción de lo que hasta ahora se había mantenido excluido, oculto, ignorado o indigno de la visibilidad histórica. Es decir, esos espacios inadvertidos que saltan al cepillar la historia a contrapelo.

Segundo estrato. En ocasiones, no se trabajará con el conjunto total de las fotografías que conformaban el reportaje sino con aquellas que fueron seleccionadas por el medio impreso. Imágenes, además, que pueden estar recortadas, reencuadradas, modificadas en su calidad técnica y, por último, recontextualizadas por el texto, titulares, pie de foto y su ubicación dentro del periódico. Un conjunto de elementos que conforme el estatus epigramático de las fotografías y del sistema de dys-posición de imágenes de la constelación fotográfica.

Asimismo, y como forma consustancial a la recolección del fragmento y de la ruina, la configuración de las constelaciones que se pretenden conformar no podrán tomar la absoluta totalidad del archivo fotográfico con el que se trabaja. De esta manera, lo que se propone es llevar a cabo una selección de los reportajes más significativos para, en torno a ellos, establecer sistemas que articulen el discurso no de forma cerrada y excluyente, sino abierta y permeable al resto de reportajes.

Tercer estrato. Si tal como señala Berlau, la verdad es concreta, singular, parcial, incompleta, pasajera como una estrella fugaz, el lector de esta constelación de estrellas fugaces, en su condición de "expectador" tendrá en los pequeños destellos fruto de la dys-posición de imágenes, textos y pies de foto y de la utilización literaria de la fotografía, trocitos de verdad dispersos aquí y allá. Se trata, por tanto, de una modesta aproximación cartográfica para dys-poner textos verbovisuales. 
Cuarto estrato. A partir del supuesto de que la visualidad y las operaciones visuales están culturalmente construidas, la revisión historiográfica que se propone queda, al tiempo, atravesada en su construcción como relato por la revalorización que plantea Sánchez Vigil (2001), Burke (2005), Cadava (2006) o Collingwood-Selby (2009) del uso la imagen fotográfica como documento histórico atendiendo, aquí, tanto al uso y usos del hecho fotográfico como a su valor heurístico, de producción de conocimiento.

Quinto estrato. La función indicial — en términos peircinaosdel documento fotográfico habrá de ser considerada, al tiempo, como parte de una cultura mediática y como engranaje de una experiencia visual ampliada - en cierto modo sinestésica- del ecosistema mediático en el que se desarrolla.

Sexo estrato. Reconocidas las cesuras que esta metodología plantea, y desplazándonos hacia espacios de enunciación esencialmente cualitativos, esta propuesta intenta interconectar las posibilidades metodológicas que ofrecen las humanidades y las ciencias sociales a la hora de plantear un ejercicio de rescritura desde el hecho fotoperiodístico aun cuando la exposición vislumbre un tono ensayístico e incluso rapsódico. Un ejercicio de narración que, a su vez, puede ensayarse desde las historias paralelas, las historias alternativas y la deconstrucción de los modos en los que la historia ha sido construida.

Séptimo estrato. Si "toda fotografía íntima puede convertirse en pública y toda fotografía pública se puede utilizar de forma íntima" (TISSERON, 2000, p. 120) esta propuesta posibilita abrir lecturas y hacer visibles espacios inadvertidos que, quizás por lo difícilmente categorizables, han estado siempre en peligro de quedar condenados 
a habitar en los márgenes de los grandes relatos de la historia. A la espera de ser cepillados a contrapelo.

Este esbozo cartográfico, sin más pretensión que la de funcionar como un mapa de bolsillo, reivindica el método de montaje mediante el uso de las fotografías de prensa de achivos y hemerotecas en un intento, también, de rescatar de un afuera historiográfico aquello que difícilmente se puede llegar a ver al estar situado entre la experiencia recordada, la recreada y lo que nos ha sido contado.

\section{Referencias}

ABRIL, Gonzalo. Análisis crítico de textos visuales. Mirar lo que nos mira. Madrid: Síntesis, 2008.

BAJTIN, Mijail. La poétique de Dostoievski. París: Seuil, 1970.

BENJAMIN, Walter. Discursos interrumpidos I. Buenos Aires: Taurus, 1989.

BENJAMIN, Walter. El libro de los pasajes. Madrid: Akal, 2005.

BENJAMIN, Walter. Imágenes que piensan. Madrid: Adaba, 2012.

BENJAMIN, Walter. La dialéctica en suspenso: fragmentos sobre la historia. Santiago: Ed. LOM, 2009.

BENJAMIN, Walter. Obras II. Madrid: Abada, 2007. v. 1.

BERLAU, Ruth. Epílogo. En: BRECHT, Bertolt. ABC de la guerra. Madrid: Ediciones del Caracol, 2004. p. 7.

BRECHT, Bertolt. ABC de la guerra. Madrid: Ediciones del Caracol, 2004. 
BUCK-MORSS, Susan: Dialéctica de la mirada: Walter Benjamín y el proyecto de los pasajes. Barcelona: La Balsa de la Medusa, 1996.

BURKE, Peter. Visto y no visto: el uso de la imagen como documento histórico. Barcelona: Ed. Biblioteca de Bolsillo, 2005.

CADAVA, Eduardo. Trazos de luz: tesis sobre la fotografía de la historia. Santiago de Chile: Ed. Palinodia, 2006.

COLLINGWOOD-SELBY, Elizabeth. El filo fotográfico de la historia. Walter Benjamin y el olvido de lo inolvidable. Santiago de Chile: Ed. Metales Pesados, 2009.

DIDI-HUBERMAN, Georges. Cuando las imágenes toman posición. Madrid: Antonio Machado Libros, 2008.

FOUCAULT, Michael. La arqueología del saber. México: Siglo XXI, 2009.

HAMBURGER, Jean. Los límites del conocimiento. México: FCE, 1986.

HERNÁNDEZ-NAVARRO, Miguel Ángel. Materializar el pasado: el artista como historiador (benjaminiano). Murcia: Editorial Micromegas, 2012.

JAMESON, Fredric. Documentos de cultura, documentos de barbarie. Madrid: Visor, 1989.

KRACAUER, Siegfried. Construcciones y perspectivas: el ornamento de la masa. Barcelona: Gedisa, 2009.

LÓPEZ CASTELLÓN, Enrique: Charles Baudelaire: obra poética completa. Madrid: Akal, 2003.

MALLARMÉ, Stéphane. Un lance de dados jamás abolirá el 
azar. Pontevedra: Maldonor Ediciones, 2013.

MITCHELL, William John Thomas. Picture theory. Chicago: U of Chicago Press, 1994.

MITCHELL, William John Thomas. Teoría de la imagen. Ensayos sobre la representación verbal y visual. Madrid: Akal, 2009.

MOHOLY-NAGY, László. La photographie dans la réclame. En: WERMESTER, Catherine. Peinture photographie film et autres écrits sur la photographie. París: Gallimard, 2007.

PEIRCE, Charles Sanders. La ciencia de la semiótica. Buenos Aires: Ediciones Nueva Visión, 1974.

ROSE, Gillian. Visual methodologies: an introduction to the interpretation of visual materials. London: Sage, 2001.

SÁNCHEZ VIGIL, Juan Miguel. La fotografía como documento en el siglo XXI. Documentación de las ciencias de la información, Madrid, ES, n. 24, p. 255-268, 2001.

TISSERON, Serge. El misterio de la cámara lúcida. Fotografía e inconsciente. Salamanca: Universidad Salamanca, 2000.

VAN DIJK, Teun A. El estudio interdisciplinario de las noticias y el discurso. En: JENSEN, Klaus Bruhn; JANKOWSKI, Nicholas W. (ed.). Metodologías cualitativas de investigación en comunicación de masas. Barcelona: Ed. Bosch, 1993. p. 135-148.

WARBURG, Aby. Atlas Mnemosyne. Madrid: Akal/ Arte y Estética, 2010.

WEIGEL, Sigrid. Cuerpo, imagen y espacio en Walter Benjamin: una relectura. Buenos Aires, Argentina: Editorial Paidós, 1999. 